\title{
Comparison of levels of chloroplast DNA diversity of two Shorea species with contrasting geographical distribution
}

\author{
Zulfahmi $^{*}$, Utari Ocsewonda Mahfira ${ }^{2}$, Ulfah Juniarti Siregar ${ }^{3}$, \\ Iskandar Zulkarnaen Siregar ${ }^{3}$, Tedy Yunanto ${ }^{4}$
}

\author{
${ }^{1}$ Department of Agrotechnology, Faculty of Agriculture and Animal Science, State Islamic University of Sultan Syarif Kasim, \\ Panam, Pekanbaru 28293, Riau, Indonesia \\ 2 Alumni of Department of Silviculture, Faculty of Forestry, Bogor Agricultural University, Kampus IPB Darmaga, Bogor 1668, Indonesia \\ ${ }^{3}$ Department of Silviculture, Faculty of Forestry, Bogor Agricultural University, Kampus IPB Darmaga, Bogor 1668, Indonesia \\ ${ }^{4}$ Directorate General of Mineral, Coal and Geothermal, Ministry of Energy and Mineral Resources, Jakarta, 12870 Indonesia
}

Received 7 March 2015/ Accepted 31 July 2015

\begin{abstract}
The analysis of the distribution of genetic diversity in a species provides useful information for conservation programs and management at the species level. The objective of this study was to observe the distribution of chloroplast DNA haplotypes and to assess their variation within and among populations of two Shorea species. Results of this study showed that each of the two species was characterized by a different common haplotype. Polymorphisms were found in each species, but the overall haplotype variation was low due to the low number of cpSSR markers investigated. A low level of intra-specific variation was detected in natural populations of $S$. parvifolia and $S$. laevis in which only three haplotypes and four haplotypes were found, respectively. A strong differentiation among populations of $S$. parvifolia and $S$. laevis were observed $\left(\mathrm{G}_{\mathrm{ST}}=0.582\right.$ and $\mathrm{G}_{\mathrm{ST}}=0.736$, respectively), indicating limited gene flow among populations of two Shorea species. Despite its restricted distribution, $S$. laevis exhibited higher genetic diversity than the more widespread S. parvifolia. It is clear that the expectation of reduced genetic diversity in species with restricted distribution is not always borne out. Geographical distribution of haplotypes did not clearly reflect the distribution of two Shorea species populations. The findings of this study could be utilized as basic information to conserve the sources of genetic diversity in S. parvifolia and S. laevis in the future.
\end{abstract}

Keywords: Chloroplast microsatellite, Genetic variation, Shorea laevis, Shorea parvifolia.

\section{INTRODUCTION}

Shorea parvifolia and Shorea laevis are members of genus Shorea (Kamiya et al., 2005) and plays significant economic and ecological roles in Indonesia. The hard wood of these species are suitable for plywood, veneer, heavy construction, flooring, furniture, window panels, doors, and stairs. In Indonesia, S. parvifolia is locally known as meranti sarang punai and have become target species for commercial plantations and reforestations due to their fast growth rates compared to other dipterocarps. S. parvifolia is a long-lived tree species; adults can reach $65 \mathrm{~m}$ in height and $200 \mathrm{~cm}$ in diameter at breast height (Newman et al., 1996a, b), which grows well and even abundantly in lowland to upper hill land at altitudes of up to $800 \mathrm{~m}$ above sea level (Ashton, 1982).

Shorea laevis is locally known as balau or sometimes bangkirai. This species of emergent tree can reach 60 $\mathrm{m}$ tall and up to $240 \mathrm{~cm}$ in diameter, and grows well in undisturbed mixed dipterocarp forests up to $600 \mathrm{~m}$ altitude, hillsides, ridges and alluvial sites to sandy soils. S. laevis is classified in a 'lower risk/least concern species category' according to red list of the IUCN (International Union for Conservation of Nature of Natural Resources) (Ashton,
1998). Both S. parvifolia and S. laevis reproduce sexually with cross pollination systems and are pollinated by less energetic insects as beetle and thrips (Sakai et al., 1999). The seeds of two species are dispersed by wind and gravity and their natural distribution covers two big islands in Indonesia. According to Ashton (1982) and Newman et al. (1996a, b). S. parvifolia is the most common Shorea species and is widely distributed in Sumatra and Borneo while $S$. laevis is restricted to northern Sumatra (Aceh) (Newman et al., 1996b) and commonly in Borneo (Newman et al., 1996a).

Conservation of these species is important due to their habitat losses as an impact of human activities such as over exploitation, and land use changes leading to further losses of genetic diversity at species and population levels. Deforestation can eliminate partial or entire populations

\footnotetext{
* Author for correspondence: Zulfahmi,

Department of Agrotechnology, Faculty of Agriculture and

Animal Science, State Islamic University of Sultan Syarif Kasim,

Panam, Pekanbaru 28293, Riau, Indonesia.

Tel.: +62-761-562051, Fax: +62-761-562052

Email-zulfahmi@uin-suska.ac.id.
} 
of species and reduces the genetic diversity of residual populations. Currently, conservation activities of these species have been performed but did not consider the genetic information gained based on DNA markers. Until now, studies into genetic variation of $S$. parvifolia in Indonesia have been conducted based on various markers targeted at nuclear DNA, such as AFLP (Cao et al., 2006; 2009), SCAR (Nuroniah, 2010), and sequencing of five nuclear gene regions (Iwanaga et al., 2012). Information on the population genetic structure is unavailable for S. laevis, but Masuda et al. (2010) have reported the isolation and characterization of SSR markers in S. maxwelliana and $S$. laevis. However, investigation using chloroplast DNA is limited for both species and related to the population numbers and represented species. Indrioko (2007) carried out analysis of chloroplast DNA from a few sample of four Shorea species using PCR-RFLP and microsatellite analysis, and Tsumura et al. (2011) have done sequencing analysis on many species of Shorea but these do not represent the population distribution of all species.

As we know, S. parvifolia has a broader geographical distribution than S. laevis (Ashton, 1982; Newman et al., 1996a, b). Plant species with restricted geographical distribution tend to have lower genetic variation than their more widespread congeners (Karron, 1987; Gitzendanner and Soltis, 2000), and species' restricted distribution renders them more vulnerable than more widespread species to threats such as plant collectors and habitat degradation (Srimuang et al., 2010). Therefore, we need to recognize that the Shorea species, S. parvifolia and S. laevis are widely distributed and restricted in distribution, respectively. Analysis of thedistribution ofgenetic diversity and population structure in species that are widely distributed or with a more restricted distribution is crucial as a basis for formulating an effective strategy for conservation and sustainable utilization of the genetic resources. Long-term survival and evolution of species depend on the maintenance of sufficient genetic variation within and among populations to adapt to environmental changes. Within a species, genetic diversity of a plant's population is largely determined by factors such as genetic drift, gene flow, mating system and mode of reproduction, as well as its evolution and life history.

The use of DNA-based molecular marker techniques in studies of the genetic diversity of forest tree species has significantly increased (Semagn et al., 2006; Spooner et al., 2005), in particular of those markers displaying high polymorphism like microsatellites. Microsatellites, also called simple sequence repeats (SSRs), are short DNA sequence stretches in which a single motif consisting of one to six bases is tandemly repeated (Schlötterer, 1998; 2000). Microsatellite markers are characterized by a high degree of polymorphism, co-dominant inheritance, high genomic abundance (Schlötterer, 1998; 2000; Weising et al., 2005). In addition, it is easy to assess size variation using the polymerase chain reaction (PCR) with pairs of flanking primers (Weising et al., 2005). These attributes make microsatellites more powerful and popular in the analysis of population genetic structures and when addressing phylogeographical issues in plant species. Microsatellite markers have been developed for Shorea species including S. parvifolia and S. laevis (Lee et al., 2004; $\mathrm{Ng}$ et al., 2009; Masuda et al., 2010). In this study, we analyzed the chloroplast genome using microsatellite markers. In plants, chloroplast DNA has slow mutation and recombination rates, and thus it is a good tool for studying genetic variation of closely related species, or at the intraspecific level, particular of non-coding regions (Yamane et al., 2006). Chloroplast DNA is known to be maternally inherited in most angiosperms (Petit et al., 2005) and thus gene flow or haplotype exchange occurs exclusively by seed. Maternally inherited markers generally reveal much greater genetic structure than nuclear markers, are smaller than nuclear markers, and have a smaller effective population size than nuclear DNA (Petit et al., 2005). Analysis of chloroplast microsatellites has often been applied to the study of population genetic structures of forest trees (Li et al., 2012; Derero et al., 2010; Zulfahmi et al., 2010; Ayele et al., 2009; Pakkad et al., 2008; Setsuko et al., 2007), phylogeography (Scotti-Saintagne et al., 2013; Ferreira et al., 2011; Duminil et al., 2010; Grassi et al., 2006), colonization history (Dainou et al., 2010; Heuertz et al., 2004), and detection of the geographic origin of species (Deguilloux et al., 2004). The objectives of this research were to determine the distribution of chloroplast DNA haplotypes, including estimated genetic diversity of chloroplast DNA, within and between populations of S. parvifolia and S. laevis using microsatellite markers and to formulate directives for genetic conservation of the target species.

\section{MATERIALS AND METHODS}

Sample collection. Leaf samples of Shorea parvifolia were collected from seven natural populations, four populations from Sumatra (Pasir Mayang, Bukit Tigapuluh National Park, Asialog, and Nanjak Makmur) and three populations from Borneo (Sumalindo, Sari Bumi Kusuma and Batu Ampar). The reason for exclusion of Aceh from sampling is the security problems preventing safe sample collection. In addition, this area is not dominated by dipterocarp species, but by the Pinus merkusii plant. A total of 44 individuals were sampled from seven different geographic locations for S. parvifolia.

For Shorea laevis, leaf samples were also collected from seven representative natural populations located across west Borneo (Suka Jaya Makmur population), central Borneo (Sari Bumi Kusuma and Sarpatim Populations) and East Borneo (Berau, Batu Ampar, Bangkirai and ITCI Karya Utama populations). In total, 35 individuals of S. laevis were analyzed in this study. 
For each species, 5-10 individuals per population were collected among individuals distributed more than $50 \mathrm{~m}$ apart. Determination of the number of samples taken per population was based on reports of Pons and Petit (1995), who conclude that sampling in many populations is more important than many individuals per population, for an accurate measurement of gene diversity. Related to slow mutation rates in chloroplast DNA, two samples per population is sufficient to observe the gene diversity (Pons and Petit, 1995). Our estimates that the numbers of samples in this study are sufficient to determine the level of variation within populations using chloroplast DNA, and low haplotype variation can be detected due to the low number of cpSSR markers present. Five individuals per population has previously been shown to be sufficient (Petit et al., 2002a; 2002b; 2002c). Sampling locations and individuals collected per population are described in Table 1. Leaf tissues were taken from each individual, marked and stored in plastic bags containing silica gel. Samples were stored in a freezer at $-60^{\circ} \mathrm{C}$ until DNA extraction was performed.

DNA extraction. Total DNA was extracted following the Qiagen Dneasy kit protocol (Manufacturer: Qiagen, Hilden, Germany). The success and the quality of DNA isolation was tested on $0.8 \% \quad(\mathrm{w} / \mathrm{v})$ agarose gels.
Electrophoresis was performed using $1 \mathrm{X}$ Tris-acetate (TAE) buffer for about 30-80 minutes at 100-150 V. The quality of extracted DNA for each sample was determined by a comparison of ethidium bromide stained band intensities with a Lambda DNA standard.

Primer Screening, PCR amplification of cpSSRs, and genotyping. Ten universal primers, namely consensus chloroplast microsatellite primers (ccmp) ccmp1- ccmp10 (Weising and Gardner 1999) were initially screened in order to analyze chloroplast microsatellite variation. Two samples per population and a negative control were amplified. Out of ten chloroplast microsatellites, two markers (ccmp3 and ccmp6) revealed intraspecific variation for Shorea parvifolia; two markers (ccmp2 and ccmp10) also displayed intraspecific variation for S. laevis, and were used for further analysis. The PCR amplification of cpSSRs and genotyping followed procedure of Zulfahmi et al. (2010).

Data analysis. Haplotypes were inferred as combinations from individual allele sizes found at each locus. In analyzing fragment patterns of cpSSR, the fragments were coded with 1 and 0 to indicate the presence or absence of fragments. Haplotype frequencies and population genetic parameters (average diversity within populations $H_{s}$; total diversity

Table 1. Approximate latitude and longitude, and number of individuals each population $[\mathrm{N}]$ of S. parvifolia and S. laevis.

\begin{tabular}{|c|c|c|c|c|}
\hline Population Name & $\begin{array}{l}\text { Population } \\
\text { Abbreviation }\end{array}$ & $\mathbf{N}$ & Longitude & Latitude \\
\hline $\begin{array}{l}\text { S. parvifolia } \\
\text { Batu Ampar, East Borneo } \\
\text { Sumalindo, Central Borneo } \\
\text { Sari Bumi Kusuma,Central Borneo } \\
\text { Bukit Tigapuluh National Park, Riau } \\
\text { Nanjak Makmur, Riau } \\
\text { Ex-Asialog, Jambi } \\
\text { Pasir Mayang, Jambi } \\
\text { Total }\end{array}$ & $\begin{array}{l}\text { SP-BA } \\
\text { SP-SM } \\
\text { SP-SBK } \\
\text { SP-BTNP } \\
\text { SP-NM } \\
\text { SP-EA } \\
\text { SP-PM }\end{array}$ & $\begin{array}{c}5 \\
6 \\
7 \\
6 \\
5 \\
10 \\
5 \\
44\end{array}$ & $\begin{array}{l}116048^{\prime}-117^{\circ} 00^{\prime} \mathrm{E} \\
115 \mathrm{o} 19^{\prime}-116^{\circ} 36^{\prime} \mathrm{E} \\
111^{\circ} 39^{\prime}-112^{\circ} 25^{\prime} \mathrm{E} \\
102^{\circ} 13^{\prime}-102^{\circ} 45^{\prime} \mathrm{E} \\
101^{\circ} 30^{\prime} 37^{\prime}-103^{\circ} 21^{\prime} 36^{\prime \prime} \mathrm{E} \\
103^{\circ} 10^{\prime} 47^{\prime \prime} \mathrm{E} \\
101^{\circ} 48^{\prime} 57^{\prime \prime}-101^{\circ} 49^{\prime} 17^{\prime \prime} \mathrm{E}\end{array}$ & $\begin{array}{l}00^{\circ} 45^{\prime}-00^{\circ} 50^{\prime} \mathrm{N} \\
00^{\circ} 55^{\prime}-00^{\circ} 56^{\prime} \mathrm{N} \\
00^{\circ} 36^{\prime}-01^{\circ} 10^{\prime} \mathrm{S} \\
00^{\circ} 40^{\prime}-01^{\circ} 30^{\prime} \mathrm{S} \\
00^{\circ} 46^{\prime} 24^{\prime \prime}-00^{\circ} 24^{\prime} 34^{\prime \prime} \mathrm{S} \\
01^{\circ} 09^{\prime} 31^{\prime \prime} \mathrm{S} \\
00^{\circ} 52^{\prime} 32^{\prime \prime}-01^{\circ} 54^{\prime} 17^{\prime \prime} \mathrm{S}\end{array}$ \\
\hline $\begin{array}{l}\text { S. laevis } \\
\text { Berau, East Borneo } \\
\text { Batu Ampar, East Borneo } \\
\text { Bangkirai, East Borneo } \\
\text { ITCI Karya Utama, East Borneo } \\
\text { Sari Bumi Kusuma,Central Borneo } \\
\text { Sarpatim,Central Borneo } \\
\text { Suka Jaya Makmur, West Borneo } \\
\text { Total }\end{array}$ & $\begin{array}{l}\text { SL-BR } \\
\text { SL-BA } \\
\text { SL-BK } \\
\text { SL-IKU } \\
\text { SL-SBK } \\
\text { SL-SPT } \\
\text { SL-SKJ }\end{array}$ & $\begin{array}{l}5 \\
5 \\
5 \\
5 \\
5 \\
5 \\
5 \\
35\end{array}$ & $\begin{array}{l}116^{\circ} 49^{\prime}-117^{\circ} 24 \mathrm{BT} \\
1160^{\prime}-117 \mathrm{o} 00^{\prime} \mathrm{E} \\
11732^{\prime}-118^{\circ} 35^{\prime} \mathrm{BT} \\
116^{\circ} 17^{\prime}-1176^{\prime} \mathrm{BT} \\
111^{\circ} 39^{\prime}-112^{\circ} 25^{\prime} \mathrm{E} \\
112^{\prime} 03^{\prime} 13,7^{\prime \prime} \mathrm{BT} \\
110^{\prime} 49^{\prime} 54,2^{\prime \prime} \mathrm{BT}\end{array}$ & $\begin{array}{l}02^{\circ} 05^{\prime}-02^{\circ} 36^{\prime} \mathrm{LS} \\
00 \mathrm{o} 45^{\prime}-00 \mathrm{o} 50^{\prime} \mathrm{N} \\
00^{\circ} 14^{\prime}-01^{\circ} 15^{\prime} \mathrm{LS} \\
00^{\circ} 20^{\prime}-01^{\circ} 18^{\prime} \mathrm{LS} \\
00^{\circ} 36^{\prime}-01^{\circ} 10^{\prime} \mathrm{S} \\
01^{\prime} 0458,33^{\prime \prime} \mathrm{LS} \\
01^{\prime} 31^{\prime} 07,2^{\prime \prime} \mathrm{LS}\end{array}$ \\
\hline
\end{tabular}


$H_{T}$; differentiation among populations $G_{S T}$ ) were calculated using the POPGEN Software Version 32 (Yeh et al., 1999). Analysis of molecular variance (AMOVA) was also peformed to examine the hierarchical genetic structure using ARLEQUIN Software Version 3.5.1 (Excoffier and Lischer, 2011) with three levels of population structure for S. parvifolia i.e. between islands (Sumatra and Borneo), among populations within islands, and within populations, but two levels of population structure for $S$. laevis, i.e. among populations and within populations, since $S$. laevis is only found in Borneo. A UPGMA dendogram analysis based on Nei's genetic distance (1972) was performed with NTSYSpc Software Version 2.00 (Rohlf, 1998) to determine the genetic relationship among populations.

\section{RESULTS AND DISCUSSION}

cpSSR haplotypes. The joint analysis of both polymorphic cpSSR loci (ccmp3 and ccmp6) in Shorea parvifolia allowed the observation of three haplotypes, namely A, B, and C. The haplotypes of S. parvifolia and variants identified here are in accordance with those already published by Zulfahmi et al. (2010) in Shorea acuminata, namely $\mathrm{R}, \mathrm{S}$ and $\mathrm{U}$. Haplotype $\mathrm{A}$ was a common haplotype and found in all populations of S. parvifolia, whereas Haplotype B and C were only observed in Sari Bumi Kusuma population. For $S$. laevis, based on the combination of the two loci polymorphic cpSSR (ccmp2 and ccmp10), four haplotypes were observed: D, E, F and G. Haplotype D was a common haplotype and found in almost all populations of S. laevis, except in the Sarpatim population, whereas haplotype E, F, and G were only observed in Sarpatim, Sari Bumi Kusuma and ITCI Karya Utama populations, respectively. Details of haplotype frequencies and haplotype distribution for each Shorea species are shown in Figure 1. Two populations harbored specific haplotypes in each species, Sari Bumi Kusuma in the case of $S$. parvifolia, and Sarpatim, Sari Bumi Kusuma, ITCI Karya Utama in the case of S. laevis). These haplotype differences can be used as diagnostic markers for the identification of geographical origin of wood and seed of these Shorea species, which is valuable for the conservation of this species. The utilization of a cpDNA marker to identify the origin of wood has been developed in mahogany species (Swietenia macrophylla King) (Degen et al., 2013), Merbau species (Lowe et al., 2010), other Shorea species (Indrioko, 2007; Finkeldey et al., 2010; Tsumura et al., 2011), Neobalanocarpus heimii (Tnah et al., 2009), Gonystylus spp. (Ogden et al., 2008), and Oak species (Deguilloux et al., 2004).

Polymorphisms were found in each species, but overall haplotype variation was low, even though multiple populations were investigated for both species. The low haplotype variation of chloroplast DNA found in this study is closely related to the uniparental mode of inheritance, the absence of recombination, and, most important, low mutation rates (Jakobsson et al., 2007; Weising et al., 2005). The mutation rate measured in chloroplasts ranges from 0.8 x $10^{-9}$ (Yamane et al., 2006) to $2.8 \times 10^{-9}$ (Jakobsson et al., 2007). Substitution rates are knows to be particularly low in trees, a likely consequence of their long generation time (Kay et al., 2006; Petit and Hampe, 2006). Low haplotype diversity in Shorea species in particular has been reported in S. parvifolia (three haplotypes, Indrioko, 2007); S. johorensis (three haplotypes, Indrioko, 2007); S. acuminata (six haplotypes, Zulfahmi et al., 2010); and S. leprosula (one haplotype, Indrioko, 2007). A low number of haplotype was observed in other species using chloroplast microsatellite markers such as in Corylus avellana (three haplotypes, Leinemann et al., 2013), Cordia africana (three haplotypes, Derero et al., 2010), Jatropha curcas (four haplotypes, Mittal and Dubey, 2010), Fraxinus ornus (four haplotypes, Heuertz et al., 2006) and wild Grapevine (five haplotypes, Grassi et al., 2006).

The low cpDNA genetic diversity in this species is in contrast with other dipterocarp species studied previously using different markers, i.e. DNA sequencing. Based on DNA sequencing, a total of 21 cpDNA haplotypes were detected from 32 populations of Neobalanocarpus heimii (trn $\mathrm{L}$ intron, trnG intron, $\operatorname{trn} \mathrm{K}$ intron, and $p s b \mathrm{~K}-\operatorname{trn} S$ spacer regions, Tnah et al., 2009) and 15 haplotypes were found in eight populations of $S$. curtisii ( $\operatorname{trn} \mathrm{H}-\mathrm{psbA}-\operatorname{trn\mathrm {K}}$ and $\operatorname{trn} \mathrm{L}-\operatorname{trn} \mathrm{F}$ regions, Kamiya et al., 2012). These studies also showed that most of the populations contained multiple haplotypes, so the low level of genetic variation in S. parvifolia and S. laevis were specific in the cpDNA regions examined in this study.

Population structure. Chloroplast microsatellite variation within populations of $S$. parvifolia and $S$. laevis was low, with an average haplotype diversity value of $H_{S}=0.031$ and $H_{S}=0.046$, respectively. Total haplotype diversity in the overall sample of both species was higher than within populations (Table 2). The overall differentiation among populations was high $\left(G_{S T}=0.582\right)$. Analysis of molecular variance (AMOVA) of $S$. parvifolia is displayed in Table 4. The high variation existed within populations $(42.30 \%)$ and between populations within the island $(44.05 \%)$. Only $13.65 \%$ of total variation existed between islands. For S. laevis, the overall differentiation among populations (GST) was $0.74\left(H_{S}=0.046, H_{T}=\right.$ 0.173) (Table 3). The results of AMOVA of S. laevis indicate that $70.59 \%$ of the total genetic variation was due to differences between populations and $29.41 \%$ of the variation was due to differences within populations (Table 3).

Very low genetic and haplotype diversity within populations $\left(H_{S}=0.031\right.$ for $S$. parvifolia and $H_{S}=$ 0.046 for $S$. laevis) and very high differentiation among 

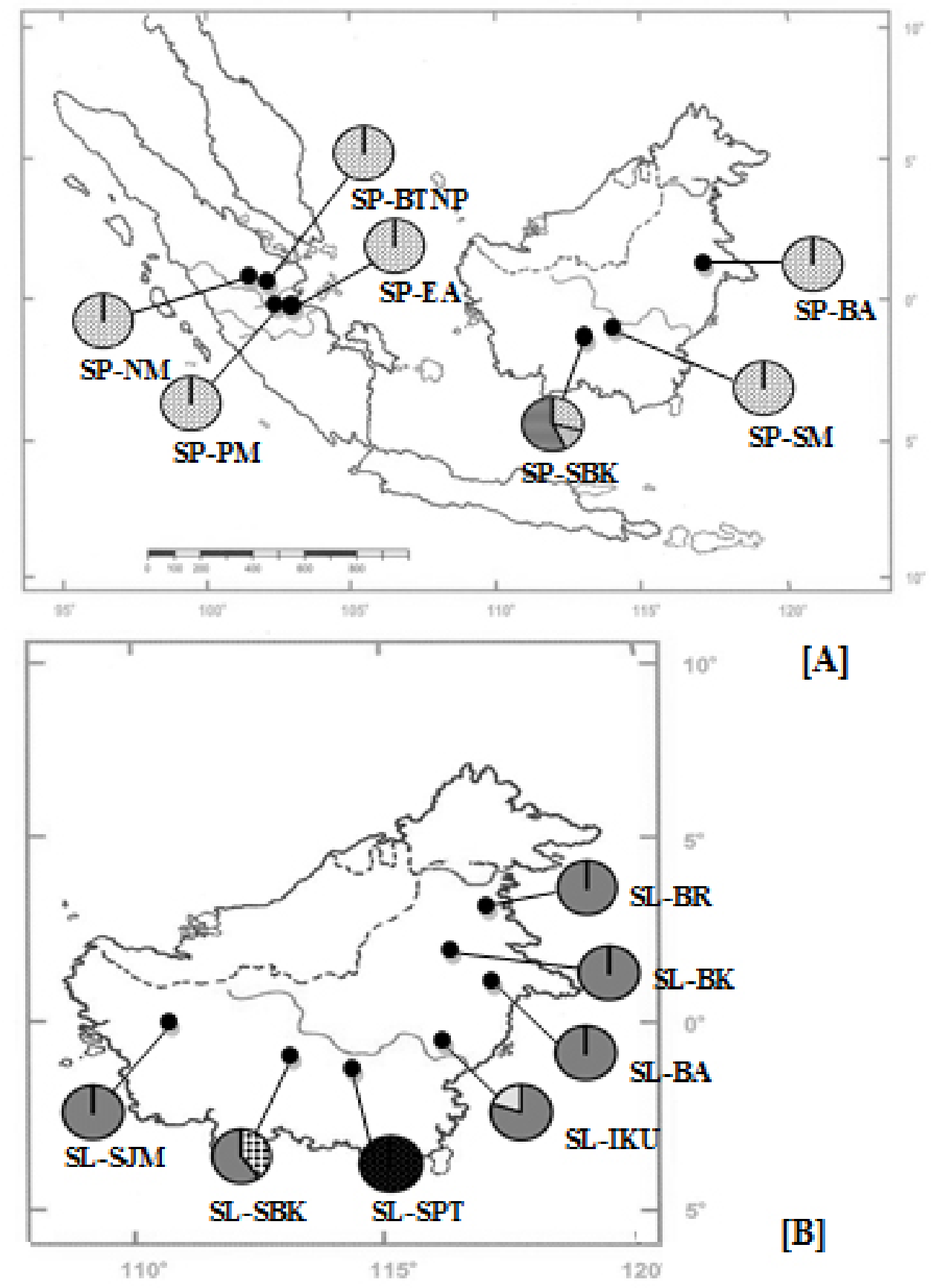

[A]

[B]

\section{Haplotype legend:}

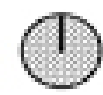

а (1)
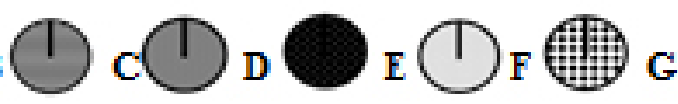

Figure 1. Geographical distribution of chloroplast microsatellite haplotypes in S. parvifolia [A] and S. laevis [B]. The haplotype frequency of each population is indicated a by pie chart. For population abbreviations see Table 1.

Tabel 2 Estimates of diversity of chloroplast miscrosatellite of S. Parvifolia and S.laevis.

\begin{tabular}{|l|c|c|c|c|}
\hline \multicolumn{1}{|c|}{ Species } & N & HS & HT & GST \\
\hline S. parvifolia & 7 & 0.031 & 0.074 & 0.582 \\
\hline S. laevis & 7 & 0.046 & 0.173 & 0.736 \\
\hline
\end{tabular}

populations (GST $=0.582$ for $S$. parvifolia and GST $=0.736$ for $S$. laevis) demonstrated a marked genetic separation of the populations. This result contrasts with low differentiation between populations and high variation within populations in other Shorea species such as S. parvifolia $(\mathrm{GST}=0.150$, Indrioko, 2007); S. acuminata $(\mathrm{GST}=0.150$, Zulfahmi et al., 2010), and may be explained by the increase 
Table 3. Analysis of molecular variance (AMOVA) of S. parvifolia and S. laevis

\begin{tabular}{|c|c|c|c|c|c|}
\hline Source variation & $\begin{array}{l}\text { degree } \\
\text { of } \\
\text { freedom }\end{array}$ & $\begin{array}{c}\text { Sum of } \\
\text { Squared } \\
\text { deviations }\end{array}$ & $\begin{array}{c}\text { Variance } \\
\text { Component }\end{array}$ & $\begin{array}{l}\text { Percentages } \\
\text { of Total } \\
\text { Variation } \\
(\%)\end{array}$ & P-value \\
\hline $\begin{array}{l}\text { Shorea parvifolia } \\
\text { Between islands } \\
\text { Among populations within island } \\
\text { Within population }\end{array}$ & $\begin{array}{c}1 \\
5 \\
39\end{array}$ & $\begin{array}{l}1.76 \\
4.54 \\
4.57\end{array}$ & $\begin{array}{l}0.04 \\
0.12 \\
0.12\end{array}$ & $\begin{array}{l}13.65 \\
44.05 \\
42.30\end{array}$ & $\begin{array}{l}<0.00 \\
<0.00 \\
<0.00\end{array}$ \\
\hline $\begin{array}{l}\text { Shorea laevis } \\
\text { Among populations } \\
\text { Within populations }\end{array}$ & $\begin{array}{c}6 \\
28\end{array}$ & $\begin{array}{c}11.14 \\
4.00\end{array}$ & $\begin{array}{l}0.34 \\
0.14\end{array}$ & $\begin{array}{l}70.59 \\
29.41\end{array}$ & $\begin{array}{l}<0.00 \\
<0.00\end{array}$ \\
\hline
\end{tabular}

of fragmentation in the study area due to illegal logging, forest fire and over-exploitation. Young and Boyle (2000) suggest that habitat fragmentation will decrease genetic variation within a population and increase inter-population genetic differentiation, effecting both short and long term population viability. Another genetic consequence of reduced populations are increased genetic drift and inbreeding ( $\mathrm{Li}$ et al., 2012). In Shorea species, an increase of selfing rates due to habitat fragmentation has been reported by Murawski et al. (1994); Obayashi et al. (2002); Naito et al. (2005); and Fukue et al. (2007).

Chloroplast DNA is generally maternally inherited in angiosperms and therefore differentiation is reflected in seeds only, but not in pollen dispersal. The strong genetic differentiation among populations of $S$. parvifolia and $S$. laevis observed here $\left(G_{S T}=0.582\right.$ and $G_{S T}=0.736$, respectively) indicate that restricted seed migration between populations of two Shorea species over an extended period is due to isolation of population by deforestation or naturally occurring barriers (mountains, valleys, rivers and geographical distance). The limited seed dispersal of these species is also assumed to be due to their relatively heavy seeds and abiotic dispersal by wind or gravity. The seed dispersal distance of $S$. parvifolia can be up to $100 \mathrm{~m}$ or even further, and more than half of the mature seeds land within $50 \mathrm{~m}$ of the parent tree under forest conditions (Takeuchi et al., 2004). Ashton (1982) reports an observation by van Steenis: during a dry spell at Bogor with strong southern wind, fruit dispersal of Shorea grown in Bogor Botanic Garden over the large lawn in front of the palace did not exceed $500 \mathrm{~m}$. The differentiation ( $G_{S T}$ values) in this study is lower than the mean $G_{S T}$ estimated in angiosperms species for maternally inherited haplotypes such as Sinocalycanthus chinensis $\left(G_{S T}=0.756\right.$, Li et al., 2012), Hegenia abyssinica $\left(G_{S T}=0.899\right.$, Ayele et al., 2009), Fraxinus ornus $\left(G_{S T}=0.983\right.$, Heuertz et al., 2006), and Fraxinus angustifolia $\left(G_{S T}=0.964\right.$, Heuertz et al., 2006), and an average GST for regional and widespread distribution of species ( 0.28 and 0.31 , respectively, Nybom, 2004).

Although many studies have demonstrated that rare tree species and species with a restricted geographic distribution tend to possess lower levels of genetic variation than widespread species (Karron, 1987; Gitzendanner and Soltis, 2000), our findings were not consistent with these; $S$. laevis showed higher genetic diversity $\left(H_{T}=0.173\right)$ than widespread species (S. parvifolia, $H_{T}=0.074$ ). Cao et al. (2009) found that rare species $S$. blumutensis exhibited higher genetic diversity than other widespread dipterocarp species and Rachmat et al. (2012) also reported that endemic species in Moluccas Island, such as $S$. selanica, displayed higher genetic diversity than $S$. javanica which has a wider distribution. Some other studies have also shown opposite findings (e.g. Eliades et al., 2011; Molin et al., 2009), finding high cpDNA genetic diversity in narrowly distributed tree species Cedrus brevifolia $\left(H_{T}=0.93\right.$; Eliades et al., 2011) and $S$. rodriguezii $\left(H_{T}=0.840\right.$; Molin et al., 2009). These results confirmed that not all types of rarity have the same genetic implications. Clearly, many other factors, such as the nature of the speciation process, life-history traits, and the recent history of population fluctuations, may affect the amount and distribution of genetic variation in plant species (Karron, 1987). However, our results need to be confirmed through studying more rare species and more populations of each species.

The genetic clustering among populations of each Shorea species is illustrated in Figure 2. UPGMA dendograms based on Nei's genetic distance (1972) divided S. parvifolia into two clusters with the Sari Bumi Kusuma population forming the first cluster, and other populations (Batu Ampar, Tering, Sumalindo, BTNP, Pasir Mayang, Nanjak Makmur and Asialog) forming a second cluster (Figure 2a). Geographic distribution of S. parvifolia is not clearly separated among islands. In this 

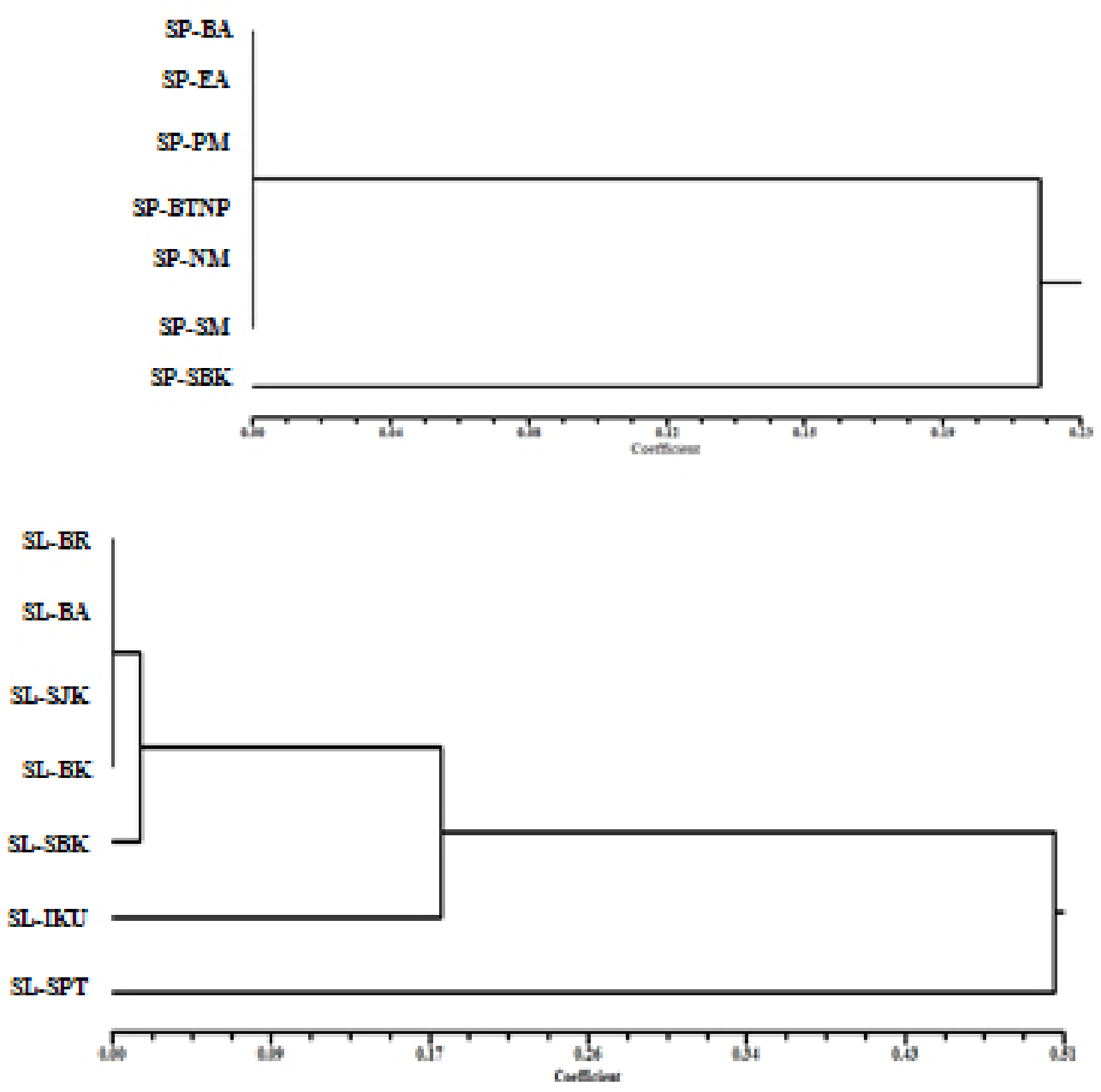

Figure 2. Dendogram (UPGMA cluster analysis) illustrating genetic differentiation in S.parvifolia [A] and S. laevis [B] populations based on Nei's genetic distance (1972). For population abbreviation, see Table 1.

study, we observed admixing between populations from Borneo (Sumalindo and Batu Ampar) clustered with the Sumatra population group. Analysis of the S. parvifolia populations based on AFLP (Cao et al., 2006) also showed them to be separated into two groups. They also found admixed populations from Sumatra and Borneo, such as the BTNP population from Sumatra clustering with the Borneo population group. A recent study by Iwanaga et al. (2012) also revealed admixture of an Asiolog population from Sumatraclustering with Borneo populations (Sari Bumi Kusuma and Sumalindo) and vice versa: one population from Borneo (ITCI Karya Utama) clustered with the Sumatra-Malay group. The chloroplast DNA haplotype A was most common in this study and has had wide distribution. These facts reflect the migration between two population groups which must have occurred in the past, and expansion of S. parvifolia into Indonesia, possibility from Borneo to the Sumatra islands or vice versa. Iwanaga et al. (2012) also estimated that migration rates of S. parvifolia in both directions were very low $\left(2 N_{e} m\right.$ per generation $<2)$, but that migration rates from Borneo to Sumatra $\left(2 N_{m}=1.65\right)$ were higher than the migration rates from Sumatra to Borneo $\left(2 N_{m}=0.25\right)$. Our study showed moderate gene flow between Sumatra and Borneo islands for $S$. parvifolia $\left(G_{S T}=13.65 \%\right)$, and this likely occurred when Sumatra and Borneo islands were connected in the last glacial time which sandy soil exposed in central Sundaland (Slik et al., 2011). Based on a species distribution model (SDM) analysis by Raes et al. (2014), climate in central Sundaland during the Late Glacial Maximum (LGM) was 
suitable for the growth of dipterocarp rainforest and acted as a bridge (contact zone) between western Sumatra andsouthern Borneo, allowing for gene flow between the two islands.

For S. laevis, UPGMA dendograms divide into four groups: the first group was the Sarpatim population; the second group was the ITCI Karya Utama population; the third group was the Sari Bumi Kusuma population; and the last group comprised the Berau, Batu Ampar, Suka Jaya Makmur, Bangkirai populations (Figure 2b). The Sarpatim population separated so far from the others because this population has a unique haplotype and is isolated geographically by mountains and valleys. The Sari Bumi Kusuma and ITCI Karya Utama populations are highly divergent from one another. This is supported by the observation that specific haplotypes were found in both populations. The West Borneo populations represented by that from Suka Jaya Makmur clustered with the East Borneo population. Many studies explain that eastern Borneo was one of the rainforest refugia at the last glacial maximum period and there was the possibility of haplotype migration from East Borneo to West Borneo via the Sari Bumi Kusuma population, but it is necessary to study this in more detail using larger samples because West Borneo is known to be an area of high species richness, as is supported by studies of the dipterocarp-dominated rainforest at Gunung Palung National Park (Cannon and Leighton, 2004). Sarpatim and Sari Bumi Kusuma populations representing Central Borneo possessed three of the four haplotypes of $S$. laevis. Petit et al. (2003) suggested that regions with a high level of genetic diversity could be identified as putative refugia, therefore our estimate indicates that Sari Bumi Kusuma, Sarpatim and ITCI Karya utama populations may have been a part of a refugia in Borneo, though more evidence is required.

The maintenance of genetic diversity is critical for the long-term survival of species, because loss of variation may significantly limit the adaptability of populations to changing environments. Shorea populations have declined due to shifting cultivation practices, forest fires, agricultural development and illegal logging, which in recent years has in Indonesia totaled about 0.61 million ha/year (Ministry of Forestry, 2014). These activities have caused severe reduction and fragmentation of populations which may now be vulnerable to genetic drift or complete loss. Our study has shown high levels of inter-population differentiation and low genetic diversity intra -population in two Shorea species. The maintenance of effective population sizes and reduction of human disturbance are thus top priority requirements for conservation. Our data also showed that many of the haplotypes were considerably rarer, and unique to a single population, and these populations should be given the highest priority for conservation of this species. For precise definition of a conservation strategy of these species, it is not appropriate to select genetic resources based only the observations of maternally inherited cpDNA markers, since the variation in cpDNA observed is not representative for neutral diversity in nuclear genome, nor for adaptive genetic variation (Finkeldey \& Mátyás, 2003). Therefore, additional study of adaptive traits is necessary. Furthermore, our results support the importance of conservation of genetic resources of comparatively rare dipterocarps and species with a restricted distribution (Cao et al., 2009). S. laevis is less common and has a more restricted distribution than $S$. parvifolia, but the diversity seen within its chloroplast genome is considerably higher than that in $S$. parvifolia. These findings in this study can be utilized as basic information to guide the conservation of the sources of genetic diversity in S. parvifolia and S. laevis in future.

\section{ACKNOWLEDGEMENTS}

The authors thank the companies involved in the study and Mr. Lukito Ari for collecting material in the field. We also thank the anonymous reviewers for helpful comments on the manuscript.

\section{REFERENCES}

Ashton, P. S. 1982. Dipterocarpaceae, in: Flora Malesiana, ed. C.G.G.J. Van Steenis, pp. 237-552. London: Martinus Nijhoff.

Ashton, P. 1998. Shorea laevis. The IUCN Red List of Threatened Species. Version 2014.3. <www.iucnredlist. org>. Downloaded on 05 December 2014.

Ayele, T. B., Gailing, O., Umer, M. And Finkeldey, R. 2009. Chloroplast DNA haplotype diversity and postglacial recolonization of Hagenia abyssinica (Bruce) J.F. Gmel. In Ethiopia. Plant Systematic Evolution 280: 175-185.

Cao, C. P., Finkeldey, R., Siregar, I. Z., Siregar, U. J. and Gailing, O. 2006. Genetic variation within and among populations of Shorea leprosula Miq and Shorea parvifolia Dyer (Dipterocarpaceae) in Indonesia detected by AFLPs. Tree Genetics and Genomes 2: 225-239.

Cao, C. P., Gailing, O., Siregar, I. Z., Siregar, U. J. and Finkeldey, R. 2009 Genetic variation in nine Shorea species (Dipterocarpaceae) in Indonesia revealed by AFLPs. Tree Genetics and Genomes 5: 407-420. 
Cannon, C. H. and Leighton, M. 2004. Tree species distribution across five habitats in a Bornean rain forest. Journal of Vegetation Science 15: 257-266.

Dainou, K., Bizoux, J. P., Doucet, J. L., Mahy, G., Hardy, O. J. and Heuertz, M. 2010. Forest refugia revisited: nSSRs and cpDNA sequences support historical isolation in a wide-spread African tree with high colonization capacity, Milicia excelsa (Moraceae). Molecular Ecology 19: 4462-4477.

Degen, B., Ward, S. E., Lemes, M. R., Navarro, C., Cavers, S. and Sebbenn, A. M. 2013. Verifying the geographic origin of mahogany (Swietenia macrophylla King) with DNA-fingerprints. Forensic Science International: Genetics 7: 55-62.

Deguilloux, M. F., Pemonge, M. H. and Petit, R. J. 2004. DNA-based control of oak wood geographic origin in the context of the cooperage industry. Annals of Forest Science 61: 97-104.

Derero, A., Gailing, O. and Finkeldey, R. 2010. Maintenance of genetic diversity in Cordia africana Lam., a declining forest tree species in Ethiopia. Tree Genetics and Genomes DOI: 10.1007/ s11295-010-0310-1.

Duminil, J., Heuertz, M., Doucet, J. L., Bouland, N., Cruaud, C., Gavory, F., Doumenge, C., Navascues, M. and Hardy, O. J. (2010. CpDNA-based species identification and phylogeography: application to African tropical tree species. Molecular Ecology doi: 10.1111/j.1365294X.2010.04917.x

Eliades, N.G.H., Gailing, O., Leinemann, L., Fady, B., Finkeldey, R. 2011. High genetic diversity and significant population structure in Cedrus brevifolia Henry, a narrow endemic Mediterranean tree from Cyprus. Plant Systematic and Evolution 294: 185-198.

Excoffier, L. and Lischer, H. 2011. Arlequin: An Integrated software package for population genetics data analysis, Ver.3.5.1. Institute of Ecology and Evolution, University of Berne. Switzerland.

Ferreira, R. C., Piredda, R., Bagnoli, F., Bellarosa, R., Attimonelli, M., Fineschi, S., Schirone, B. and Simeone, M. C. 2011. Phylogeography and conservation perspectives of an endangered macoronesian endemic: Picconia azorica (Tutin) Knobl. (Oleaceae). Eurasian Journal of Forest Research 130: 181-195.
Finkeldey, R., Leinemann, L. and Gailing, O. 2010. Molecular genetic tools to infer the origin of forest plants and wood. Applied Microbiology and Biotechnology 85: 1251-1258.

Finkeldey, R., and Mátyás, G. 2003. Genetic variation of oaks (Quercus spp.) in Switzerland. 3. Lack of impact of postglacial recolonization history on nuclear gene loci. Theoretical and Applied Genetics 106: 346-352.

Fukue, Y., Kado, T., Lee, S. L., Ng, K. K. S., Muhammad, N. and Tsumura, Y. 2007. Effects of flowering tree density on the mating system and gene flow in Shorea leprosula (Dipterocarpaceae) in Peninsular Malaysia. Journal of Plant Research 120: 413-420.

Gitzendanner, M. A. and Soltis, P. S. 2000. Patterns of genetic variation in rare and widespread plant congeners. American Journal of Botany 87: 783-792.

Grassi, F., Labra, M., Imazio, S., Rubio, R. O., Failla, O., Scienza, A. and Sala, F. 2006. Phylogeographical structure and conservation genetics of wild grapevine. Conservation Genetics 7: 837-845.

Heuertz, M., Carnevale, S., Fineschi, S., Sebastiani, F., Hausman, J. F., Paule, L. and Vendramin, G. G. 2006. Chloroplast DNA phylogeography of European ashes, Fraxinus sp. (Oleaceae): roles of hybridization and life history traits. Molecular Ecology 15: 2131-2140.

Heuertz, M., Fineschi, S., Anzidei, M., Pastorelli, R., Salvini, D., Paule, L., Lacoste, N. F., Hardy, O. J., Vekemans, X. and Vendramin, G. G. 2004. Chloroplast DNA variation and postglacial recolonization of common ash (Fraxinus excelsior L.) in Europe. Molecular Ecology 13: 3437-3452.

Indrioko, S. 2007. Geographical origin identification of four species of Shorea (Dipterocarpaceae) in Indonesia using chloroplast DNA. In Proceedings of the International Symposium on development of improved methods to identify Shorea species wood and its origin. Tokyo, September 25-26, 2007. Pp 12-18.

Iwanaga, H., Teshima, K. M., Khatab, I. A., Inomata, N., Finkeldey, R., Siregar, I. Z., Siregar, U. J. and Szmidt, A. E. 2012. Population structure and demographic history of a tropical lowland rainforest tree species Shorea parvifolia (Dipterocarpaceae) from Southeastern Asia. Journal of Ecology and Evolution 1-13. 
Jakobsson, M., Sall, T., Lind-Hallden, C. and Hallden, C. 2007. Evolution of chloroplast mononucleotide microsatellites in Arabidopsis thaliana. Theoretical and Applied Genetic 114: 223-235.

Kamiya, K., Nanami, S., Kenzo, T., Yoneda, R., Diway, B., Chong, L., Azani, M.A., Majid, N. M., Lum, S. K. Y., Wong, K. M., and Harada, K. 2012. Demographic history of Shorea curtisii (Dipterocarpaceae) inferred chloroplast DNA sequence variations. Biotropica 44: 577-585.

Kamiya, K., Harada, K., Tachida, H. and Ashton, P. S. 2005. Phylogeny of pgic gene in Shorea and its closely related genera (dipterocarpaceae), the dominant trees in Southeast Asian tropical rain forests. American Journal of Botany 92: 775-788.

Karron, J. D. 1987. A comparison of levels of genetic polymorphism and self-compatibility in geographically restricted and widespread congeners. Evolutionary Ecology 1: 47-58.

Kay, K. M., Whittal, J. B. and Hodges, S. A. 2006. A survey of nuclear ribosomal internal transcribed spacer substitution rates across angiosperms: an approximate molecular clock with life history effects. BMC Evolution Biology 6: 36.

Lee, S. L., Tani, N., Ng, K. K. S. and Tsumura, Y. 2004. Isolation and characterization of 21 microsatellite loci in an important tropical tree Shorea leprosula and their applicability to S. parvifolia. Molecular Ecology Notes 4: 222-225.

Leinemann, L., Steiner, W., Hosius, B., Kuchma, O., Arenhovel, W., Fussi, B., Haase, B., Katzel, R., Rogge, M. and Finkeldey, R. 2013. Genetic variation of chloroplast and nuclear markers in natural populations of hazelnut (Corylus avellana L.) in Germany. Plant Systematic and Evolution 299: 369-378.

Li, J., Jin, Z. and Tan, T. 2012. Genetic diversity and differentiation of Sinocalycanthus chinensis populations revealed by chloroplast microsatellite (cpSSRs) markers. Biochemical Systematic and Ecology 41: 48-54.

Lowe, A. J., Wong, K. N., Tiong, Y. S., Iyerh, S. and Chew, F. T. 2010. A DNA method to verify the integrity of timber supply chains; confirming the legal sourcing of merbau timber from logging concession to sawmill. Silvae Genetica 59: 263-272.
Masuda, S., Tani, N., Ohtani, M., Lee, S. L., Muhammad, N. and Tsumura, Y. 2010. Isolation and characterization of 12 microsatellite loci for the tropical tree species Shorea maxwelliana and S. laevis (Dipterocarpaceae). Conservation of Genetic Resources 2: 109-111.

Molins, A., Mayol, M. and Rossello, J. A. 2009. Phylogeographical structure in the coastal species Senecio rodriguezii (Asteraceae), a narrowly distributed endemic Mediterranean plant. Journal of Biogeography 36: $1372-1383$.

Mittal, N. and Dubey, A. K. 2010. A novel set of highly polymorphic chloroplast microsatellite and ISSR markers for the biofuel crop Jatropha curcas. Eurasian Journal of BioSciences 4: 119-131.

Ministry of Forestry. 2014. Forestry statistic of Indonesia 2013. Ministry of Forestry. Jakarta.

Murawski, D. A., Gunatilleke, I. A. U. N. and Bawa, K. S. 1994. The effects of selective logging on inbreeding in Shorea megistophylla (Dipterocarpaceae) from Sri Lanka. Conservation Biology 8: 997-1002.

Naito, Y., Konuma, A., Iwata, H., Suyama, Y., Seiwa, K., Okuda, T., Lee, S. L., Muhammad, N. and Tsumura, Y. 2005. Selfing and inbreeding depressioninseedsandseedlingsofNeobalanocarpusheimii (Dipterocarpaceae). Journal of Plant Research 118: 423430 .

Newman, M. F., Burgess, P. F. and Whitmore, T. C. 1996a. Manuals of dipterocarps for foresters: Borneo island light hardwoods. Jakarta: Center for International Forestry Research.

Newman, M. F., Burgess, P. F. and Whitmore, T. C. $1996 \mathrm{~b}$. Manuals of dipterocarps for foresters: Sumatra island light hardwoods. Jakarta: Center for International Forestry Research.

Ng, K. K. K., Lee, S. L., Tsumura, Y., Ueno, S., Ng, C. C. and Lee, C. T. 2009. Expressed sequence tag -simple sequence repeats isolated from Shorea leprosula and their transferability to 36 species within the Dipterocarpaceae. Molecular Ecology Resources 9: 393-398.

Nuroniah, H. S., Gailing, O. and Finkeldey, R. 2010. Development of SCAR markers for species identification in the genus Shorea (Dipterocarpaceae). Silvae Genetica 59: 249-256. 
Nybom, H. 2004. Comparison of different nuclear DNA markers for estimating intraspecific genetic diversity in plants. Molecular Ecology 13: 1143-1155.

Obayashi, K., Tsumura, Y., Ujino T. I., Niiyama, K., Tanouchi, H., Suyama, Y., Washitani, I., Lee, C. T., Lee, S. L. and Muhammad, N. 2002. Genetic diversity and outcrossing rate between undisturbed and selectively logged forests of Shorea curtisii (Dipterocarpaceae) using microsatellite DNA analysis. International Journal of Plant Science 163: 151-158.

Ogden, R., McGough, H. N., Cowan, R. S., Chua, L., Groves, M. and McEwing, R. 2008. SNP-based method for the genetic identification of ramin Gonystylus spp. Timber and products: applied research meeting CITES enforcement needs. Endangered Species Research. Doi: 10.3354/esr00141.

Pakkad, G., Ueno, S. and Yoshimaru, H. 2008. Genetic diversity and differentiation of Quercus semiserrata Roxb. in northern Thailand revealed by nuclear and chloroplast microsatellite markers. Forest Ecology and Management 255: 1067-1077.

Petit, R. J., Csaikl, U. M., Bordács, S., Burg, K., Coart, E., Cottrell, J., van Dam, B., Deans, J. D., Dumolin-Lapègue, S., Fineschi, S., Finkeldey, R., Gillies, A., Glaz,I., Goicoechea, P. G., Jensen, J. S., König, A. O., Lowe, A. J., Madsen, S. F., Mátyá, G., Munro, R. C., Olalde, M., Pemonge, M.-H., Popescu, F., Slade, D., Tabbenere, H., and urchini, D., de Vries, S. G. M., Ziegenhagen, B., and Kremer, A. 2002a Chloroplast DNA variation in European white oaks Phylogeography and patterns of diversity based on data from over 2600 populations. Forest Ecology and Management 156: 5-26.

Petit. R. J., Brewer, S., Bordács, S., Burg, K., Cheddadi, R., Coart, E., Cottrell, J., Csaikl, U. M., van Dam, B., Deans, J. D., Espinel, S., Fineschi, S., Finkeldey, R., Glaz, I., Goicoechea, P. G., Jensen, J. S., König, A. O., Lowe, A. J., Madsen, S. F., Mátyás, G., Munro, R. C., Popescu, F., Slade, D., Tabbener, H., de Vries, S. G. M., Ziegenhagen, B., de Beaulieu, J.-L., Kremer, A. 2002 b. Identification of refugia and post-glacial colonisation routes of European white oaks based on chloroplast DNA and fossil pollen evidence. Forest Ecology and Management 156: 49-74.

Petit. R. J., Latouche-Hallé, C., Pemonge, M.-H., Kremer, A. 2002c. Chloroplast DNA variation of oaks in France and the influence of forest fragmentation on genetic diversity. Forest Ecology and Management 156: 115-129.
Petit, R. J., Aguinagalde, I., de Beaulieu, J. L., Bittkau, C., Brewer, S., Cheddadi, R., Ennos, R., Fineschi, S., Grivet, D., Lascoux, M., Mohanty, A., Muller-Starck, G., Demesure-Musch, B., Palme, A., Martin, J. P., Rendell, S., Vendramin, G. G. 2003. Glacial refugia: hotspots but not melting pots of genetic diversity. Science 300: 1563-1565.

Petit, R. J., Duminil, J., Fineschi, S., Hampe, A., Salvini, D. and Vendramin, G. G. 2005. Comparative organization of chloroplast, mitochondrial and nuclear diversity in plant populations. Molecular Ecology 14: 689-701.

Petit, R. J. and Hampe, A. 2006. Some evolutionary consequences of being a tree. Annual Review Ecology and Systematic 37: 187-214.

Pons, O. and Petit, R. J. 1995. Estimation, variance and optimal sampling of gene diversity. I. Haploid locus. Theoretical and Applied Genetics 90: 462-470.

Rachmat, H. H., Kamiya, K., Harada, K. 2012. Contrasting cpDNA variation in two Indonesian endemic lowland dipterocarp species and implications for their conservation. Pakistan Journal of Biological Sciences 15: 783-788.

Raes, N., Cannon, C. H., Hijmans, R. J., Piessens, T., Saw, L. G., van Welzen, P. C. and Slik J. W. F. 2014. Historical distribution of Sundaland's Dipterocarp rainforests at Quaternary glacial maxima. Proceeding of National Academy of Science of the United State of America 1-6.

Rohlf, F. J. 1998. NTSYS-pc version 2.0. Numerical taxonomy and multivariate analysis system. New York: Applied Biostatistics Inc.

Sakai, S., Mamose, K., Yumoto, T., Kato, M. and Inoue, T. 1999. Beetle pollination of Shorea Parvifolia (SectionMutica,Dipterocarpaceae) inageneralFlowering period in Serawak, Malaysia. American Journal of Botany 86(1): 62-69.

Schlötterer, C. 2000. Evolutionary dynamics of microsatellite DNA. Chromosoma 109:365-371.

Schlötterer, C. 1998. Genome evolution: Are microsatellites really simple sequences?. Current Biology 8(4):132-134.

Scotti-Saintagne, C., Dick, C. W., Caron, H., Vendramin, G. G., Guichoux, E., Buonamici, A., Duret, C., Sire, P., Valencia, R., Lemes, M. R., Gribel, R. and Scotti, I. 2013. Phylogeography of a species complex of lowland Neotropical rain forest trees (Carapa, Meliaceae). Journal of Biogeography 40: 676-692. 
Semagn, K., Bjørnstad, Å. and Ndjiondjop, M. N. 2006. An overview of molecular marker methods for plants. African Journal of Biotechnology 5: 2540-2568.

Setsuko, S., Ishida, K., Ueno, S., Tsumura, Y. and Tomaru, N. 2007. Population differentiation and gene flow within a metapopulation of a threatened tree, Magnolia stellata (Magnoliaceae). American Journal of Botany 94: 128-136.

Slik, J. W. F., Shin-Ichiro, A., Bastian, M., Brearley, F. Q., Cannon, C. H., Eichhorn, K. A. O., Fredriksson, G., Kartawinata, K., Laumonier, Y., Mansor, A., Marjokorpi, A., Meijaard, E., Morley, R. J., Nagamasu, H., Nilus, R., Nurtjahya, E., Payne, J., Permana, A., Poulsen, A. D., Raes, N., Riswan, S., van Schaik, C. P., Sheil, D., Sidiyasa, K., Suzuki, E., van Valkenburg, J. L. C. H., Webb, C. O., Wich, S., Yoneda, T., Zakaria, R. and Zweifel, N. 2011. Soils on exposed Sunda Shelf shaped biogeographic patterns in the equatorial forests of Southeast Asia, Proceeding of National Academy of Science of the United State of America 108 (30): 12343-12347.

Spooner, D., Van-Treuren, R. and De-Vicente, M. C. 2005. Molecular Markers for Gene Bank Management. IPGRI Technical Bulletin No. 10. Rome: International Plant Genetic Resources Institute.

Srimuang, K. O., Watthana, S., Pedersen, H. A., Rangsayatorn, N. and Eungwanichayapant, P. D. 2010. Aspects of biosubsistence in Sirindhornia (Orchidaceae): are the narrow endemic more reproductively restricted than their widespread relative? Annales Botanici Fennici 47: 449-459.

Takeuchi, Y., Ichikawa, S., Konuma, A., Tomaru, N., Niiyama, K., Lee, S. L., Muhammad, N. and Tsumura, Y. 2004. Comparison of the fine-scale genetic structure of three dipterocarp species. Heredity 92: 323-328.

Tnah, L. H., Lee, S. L., Ng, K. K. S., Tani, N., Bhassu, S. and Othman, R. Y. 2009. Geographical traceability of an important tropical timber (Neobalanocarpus heimii) inferred from chloroplast DNA. Forest Ecology and Management 258: 1918-1923.

Tsumura, Y., Kado, T., Yoshida, K., Abe, H., Ohtani, M., Taguchi, Y., Fukue, Y., Tani, N., Ueno, S., Yoshimura, K., Kamiya, K., Harada, K., Takeuchi, Y., Diway, B., Finkeldey, R., Na'iem, M., Indrioko, S., Ng, K. K. S., Muhammad, N. and Lee, S. L. 2011. Molecular database for classifying Shorea species (Dipterocarpaceae) and techniques for checking the legitimacy of timber and wood products. Journal of Plant Research 124: 35-48.
Young, A. G. and Boyle, T. J. 2000. Forest fragmentation. In Forest Conservation Genetic: principles and practice, ed. A.Young, D. Boshier and T. Boyle. pp.123-134. Australia: CSIRO Publishing.

Yeh, F. C., Yang, R. and Boyle, T. 1999. POPGEN Version 1.31. Microsoft Window based for population genetic analysis. Canada: Department of Renewable Resources, University of Alberta.

Weising, K., Nybom, H., Wolf, K. and Kahl, G. 2005. DNA fingerprinting in plants: principles, methods, and applications. United State of America: CRS Press.

Weising, K. and Gardener, R. C. 1999. A set of Conserved PCR primers for the analysis of simple sequence repeat polymorphism in chloroplast genome of dicotyledonous Angiosperms. Genome 42: 9-19.

Yamane, K., Yano, K. and Kawahara, T. 2006. Pattern and Rate of Indel Evolution Inferred from Whole Chloroplast Intergenic Regions in Sugarcane, Maize and Rice. DNA Research 13: 197-204.

Zulfahmi, Siregar, I. Z. and Siregar, U. J. 2010. Chloroplast DNA variation of Shorea acuminata Dyer in Eastern Sumatra assessed by microsatellite markers. Biodiversitas 11: 107-111. 